\title{
Vocal Communication in Nonhuman Animals: View from the Wings
}

\author{
Irene M. Pepperberg
}

Department of Psychology, Harvard University

Corresponding author (Email: impepper@media.mit.edu; impepper@wjh.harvard.edu)

Citation - Pepperberg, I. M. (2020). Vocal communication in nonhuman animals: View from the wings. Animal Behavior and Cognition, 7(2), 95-100. doi: https://doi.org/10.26451/abc.07.02.03.2020

\begin{abstract}
Forty years ago, Seyfarth, Cheney, and Marler published two papers claiming semanticity for wild vervet monkey alarms calls. The papers arrived at an extremely interesting and active time in the study of animal behavior - a period during which researchers, working both in the laboratory and the field, were trying to learn as much as possible about many forms of nonhuman communication systems, were trying to teach nonhuman subjects aspects of human systems, were delving into many aspects of language evolution, and were engaging in heated debates on all these topics. Having been actively engaged in this area at the time, I present a brief memoir of the period.
\end{abstract}

Keywords - Dorothy Cheney, Animal communication, Personal memoir, Vervet monkey, Birdsong

To understand the ramifications of the Seyfarth, Cheney, and Marler (1980a,b) papers, one must appreciate their context - what was taking place in behavioral research in that time period. Not only the studies that directly preceded their findings, but also the contemporary general understanding of animal behavior, derived from experiments both in the laboratory and the field-a separation that often highlighted the then prevalent nature-nurture controversy, which was also reflected in the different foci of psychological and ethological research. One must take into account not only the work on nonhuman primates, but also research in the emerging field of birdsong, where the vervet study most likely had its roots. Moreover, a renewed interest had concurrently arisen in the evolution of language, including its possible precursors in nonhuman species (e.g., Lieberman, 1975). And, in 1973, for the first time ever, a Nobel prize had been awarded to three ethologists - von Frish, Tinbergen, and Lorenz - all of whose research on animal behavior had been, either directly or indirectly, related to communication. The vervet data would therefore have seemed to be a welcome, if far from earth-shaking, addition to the corpus of material being published at the time. Such was not the case. Thus, a brief memoir from a researcher working on related issues in that era....

It begins with recognizing that the desire of humans to understand nonhuman communication systems is not a recent phenomenon. One can point to the legend of King Solomon's ring, which purportedly enabled him to communicate at will with all the birds and beasts in his realm (Lorenz, 1952), to the historic lore of Native Americans, who supposedly could change into various animals and thus share their lives (Rasmussen, 1972), or to the many children's books on the subject (e.g., the Dr. Doolittle series). It was only in the mid-1900s, however, that humans started to develop scientific methods and acquire the technological equipment and expertise (e.g., somewhat portable tape recorders, Sonagraph ${ }^{\odot}$ analysis equipment, the ability to perform playback studies) that enabled them to begin to provide real 
data about the meaning of various species' signals, particularly in the realm of birdsong. Researchers such as Dilger (1956) showed that thrushes used song to distinguish subspecies from one another, Weeden and Falls (1959) revealed that ovenbirds used their songs for individual recognition; somewhat later studies such as those by Krebs (1977) and Kroodsma (1976) provided data to demonstrate the validity of early proposals that song had specific purposes - territorial defense and mate attraction (Howard, 1920). Marler (1961) and Smith (1963) separately systematized the analyses of nonhuman communication systems, drawing heavily on avian studies. Marler (1970) and Thorpe (1974), based on pioneering studies by researchers like Nottebohm $(1966,1970)$, also suggested that because birds - like humans and unlike nonhuman primates - were vocal learners (and, like humans, have lateralized brain areas responsible for such acquisition), they could be better models than nonhuman primates for studying the evolution of language.

In contrast, equally exciting contemporary studies by Gardner and Gardner (1969), Premack (1971), and Rumbaugh and his colleagues (1973) took a separate path for studying language evolution, and attempted to establish communication with nonhumans. These researchers showed that nonhuman primates, via a number of different routes (respectively, American sign language, noniconic plastic chips, and a computer interface) could acquire some level of referential communication - symbolic signaling, where individual symbols stood for individual objects, actions, and attributes; thus, at least a few aspects of human language could be acquired by nonhumans. The idea was that acquisition of such symbols could not occur without some underlying cognitive understanding of semantics; that is, training could not instill reference but had to bootstrap on an existent ability, and hence that the underpinnings of reference had to be present in the animals' own systems - thereby implying that nonhuman systems could indeed be a precursor of, or some basis for, human language. But no definitive evidence for such reference had yet been found in nonhuman primate signaling systems in nature, and the evidence from birds was still limited. Furthermore, earlier that year a conference at the New York Academy of Sciences had raised questions about the validity of all the laboratory-based "animal language" studies (see Marx, 1980; Wade, 1980; for the conference proceedings, see Sebeok \& Rosenthal, 1981), thereby purportedly refuting the possibility, albeit indirectly, that nonhuman primate communication in nature could have any semanticity whatsoever.

It was into this milieu that the Seyfarth, Cheney, and Marler (1980a,b) papers were published, arguing that, indeed, vervet monkeys had such referential, vocal signaling. Interestingly, Struhsaker (1967) had suggested this possibility for vervet signals more than a decade earlier, but his data seemed to languish until the ape studies implied that such behavior was possible, and until Griffin $(1976,1978)$ wrote books and articles arguing for advanced cognitive processing in nonhumans, animal consciousness, and for using communication studies as a window into the animal mind. Proponents of animal language studies used the vervet papers to argue against the claims of the nay-sayers, even though the vervet study stirred up considerable controversy on its own. [For example: The issue that, unlike humans, the vervets could not "discuss" predators outside of alarm calling in their presence — see Bickerton (1990) — was initially broached even by Marler (1974) as an argument for the calls simply being context-dependent (i.e., merely indicating 'danger above' versus 'danger below' instead of referring to specific predators).] The controversy continues to this day (e.g., Fischer, 2011; Wheeler \& Fischer, 2012; note also Townsend \& Manser, 2013), and even Seyfarth and Cheney eventually backed off somewhat in the strength of their claims of pure semanticity divorced entirely from context (see Price et al., 2014). Interestingly, no one seemed to notice - probably because the subjects were birds, the research was observational rather than experimental, and the material was not published in prestigious journals - the existence of concurrent reports that some parrots also exhibited individual vocal recognition and alarm calling suggestive of sentinel behavior that alerted the flock to various flying predators (Lawson \& Lanning, 1980; Levinson, 1980), and therefore the possibility of the same sort of signaling as seen in vervets.

I am sure others will discuss the implications of the vervet papers for research on nonhuman primates; I will look rather at what they represented for the field of animal behavior in more general terms. Two points of interest: First, although these papers made the strongest claims for semanticity at the time, they were two of many that were being published that argued for or against the possibility of meaning in nonhuman vocalizations - an indication of an amazing confluence of work that was underway 
in numerous species (note the references below). Second, even though the papers focused on monkeys, it seemed no coincidence to me that the work emanated from Marler's Millbrook Laboratory at Rockefeller University, a place well-known as one of the centers for the study of birdsong - how song was acquired and its function. Given that Marler's initial work was on chaffinch vocal behavior (Marler, 1952, 1956), it appeared likely that his interest in the development, use, and particularly the evolution of vocal communication was the impetus for the nonhuman primate research. The obvious (at least to me) rationale was that if birds' communication systems could be so complex, how could those of nonhuman primates - creatures far more closely related to humans - be any less so? Over the years, I had many disagreements with Marler, but what was undeniable was how research from Rockefeller, along with concurrent studies in places like Bielefeld, St. Andrews, and Oxford (from the labs of Immelmann, Slater, and Krebs), among others, and research by students who had graduated from a number of different laboratories, led to what was a golden period in the study of avian vocal communication, even with all the controversies therein. If the birdsong studies inspired researchers to expand their purview to vocal communication in a wide variety of nonhuman primate species (e.g., Gautier \& Gautier-Hion, 1977; Sherman, 1977; Waser, 1977), studies on vervets also inspired those who would continue to examine similar abilities in birds [NB: Elowson and Hailman's (1991) research on discrete alarms calls in Florida scrub jays (Aphelocoma c. coerulescens)].

Another existent issue around the time of the vervet publications, and on which they had some impact, was the striking dichotomy in how the study of nonhuman abilities was viewed by psychologists (mostly proponents of the 'nurture', tabula rasa viewpoint), versus biologists (mostly proponents of the 'nature' viewpoint, often focusing on behaviors such as innate-releasing-mechanisms). This dichotomy was reflected in the various approaches to the study of language evolution - was language something that was merely taught to humans (e.g., Skinner, 1957), and thus teachable to other creatures, or was it an innately specified behavior, and thus a uniquely human characteristic (e.g., Chomsky, 1959)? Were nonhuman communication systems - or any forms of behavior - totally learned or innate? As someone who in 1980 had fairly recently switched into research on avian-human vocal communication and was voraciously reading any scientific article that I found relevant, I was very much aware of the difference between what was being published in psychological versus ethological journals on behavioral research, particularly with respect to communication and avian abilities. As I noted above, cognitive processing would seem to be a prerequisite for resolving the meaning of vocalizations, but the cognitive revolution in human behavior was barely beginning to affect nonhuman research (see, for example, Hulse et al., 1978). The majority of papers in psychological journals (see Burghardt, 2006) generally involved rodents or pigeons performing some kind of experiment using operant conditioning, usually with researchers expressing relatively low expectations for the extent of avian cognitive processing (if it were mentioned at all), and studies rarely dealt with avian communication (NB: the precursor to the Journal of Comparative Psychology did publish Marler's 1970 paper comparing birdsong with children's acquisition of speech, but that was one of the notable exceptions; interestingly, Marler argued for species-specific, rigid templates for acquisition at the same time that he demonstrated significant aspects of learning). Ethological and biological journals and related review volumes, in contrast, involved studies on a wide range of avian species, examining communicative abilities both in the laboratory and in the field (e.g., Baptista et al., 1981; Güttinger, 1977; Immelmann, 1984; King \& West, 1977, 1983; Krebs et al., 1978; Kroodsma, 1979; Payne, 1982; Slater, 1983; Yasukawa, 1981), as well as those on nonhuman primates (e.g., Snowdon et al., 1982).

Thus, when the vervet papers were released, two camps clearly existed with respect to the interpretation of nonhuman abilities, and scientists interested in bridging the gap were rarely welcome in either camp, particularly with respect to communication studies. The Nobel having been awarded exclusively to ethologists did not help matters, nor did the backlash against the mostly-psychologist researchers who had been in charge of the animal language studies. The extent of the schism became personal when I submitted my first paper on functional vocalizations in a Grey parrot (Pepperberg, 1981 - a study on referential labeling). American journals - even those ostensibly on the biological side - aware of the storm brewing in the animal language field, wanted nothing to do with it. I finally sent the paper to the Zeitschrift für Tierpsychologie (now Ethology); my rationale was that they had published 
an earlier paper on Grey parrot vocal learning (Todt, 1975). That Marler, with his interest in referential animal vocalizations, was an editor also seemed fortuitous. Zeitschrift was one of the premier places to publish in the world, but the rift between psychology and ethology was never clearer as when my American colleagues derided it as some "obscure German journal" while criticizing one of my grant proposals. It seemed that the field of nonhuman referential vocal communication was in danger of losing its standing in the scientific community. Papers coming out of "the Rock," however, served as anchors in those stormy seas, particularly as they seemed to broach some of the nature-nurture divide (e.g., showing that animal calls themselves were not learned, but that youngsters did learn appropriate use over time; demonstrating aspects of learning as part of the process of birds' song acquisition).

As for the present... although studies on nonhuman vocal communication continue (including those examining comparative neuroanatomy - see, for example, Jarvis, 2019) - as do those arguing for semanticity — see, for example, Stephan and Zuberbühler (2016), the heady excitement of looking forward to each new issue of a journal, certain that it would contain another major breakthrough, is currently missing, at least in the United States. New frontiers still exist; however, in the USA the lack of funding, lack of university positions, and failure to appreciate why we need to understand the natural world means that the majority of such non-neurobiological work is now being done in Europe. But how can we understand human nature and human communication abilities if we lack an understanding of the origins of our behavior? How can we examine the evolution of vocal learning without studying how it came to exist in birds, with whom our last common ancestor was 300 million years ago? How can we design artificial intelligence systems if we limit ourselves to modeling only human intelligence? How might we be able to interpret signals from the cosmos if we cannot imagine the existence of communication systems that might be radically different from our own? Merely the findings that the architecture of the humanor primate, or even mammalian - brain is not necessary for intelligent behavior (e.g., Güntürkün \& Bugnyar, 2016; Gutiérrez-Ibáñez et al., 2018; Olkowicz et al., 2016; Rinnert et al., 2019) should alert us to the need for studying all aspects of nonhuman activities. However, we now evaluate - or re-evaluatethe detailed conclusions of the Seyfarth, Cheney and Marler papers, their impact was that they were two of several that led us, at least for a time, to think outside a narrow box; that excitement should not be forgotten.

\section{Acknowledgements}

This review was written with the support of donors to The Alex Foundation.

\section{References}

Baptista, L. F., Morton, M. L., \& Pereyra, M. E. (1981). Interspecific song mimesis by a Lincoln sparrow. Wilson Bulletin, 93, 265-267.

Bickerton, D. (1990). Language and species. Chicago: University of Chicago Press.

Burghardt, G. M. (2006). Editorial. Journal of Comparative Psychology, 120, 77-78.

Chomsky, N. (1959). A review of B.F. Skinner's "Verbal Behavior". Language, 35, 26-58.

Dilger, W. C. (1956). Hostile behavior and reproductive isolating mechanisms in the avian genera Catharus and Hylocichla. Auk, 73, 313-353.

Elowson, M., \& Hailman, J. (1991). Analysis of complex variation: Dichotomous sorting of predator-elicited calls of the Florida scrub jay. Bioacoustics, 3, 295-320.

Fischer, J. (2011). Where is the information in animal communication? In R. Menzel \& J. Fischer (Eds.), Animal thinking: Contemporary issues in comparative cognition (pp. 151-161). MIT Press.

Gardner, R. A., \& Gardner, B. T. (1969). Teaching sign language to a chimpanzee. Science, 187, 644-672.

Gautier, J.-P., \& Gautier-Hion, A. (1977). Communication in old world monkeys. In T. E. Sebeok (Ed.), How animals communicate (pp. 890-964). Indiana University Press.

Griffin, D. R. (1976). The question of animal awareness: Evolutionary continuity of mental experience. Rockefeller University Press.

Griffin, D. R. (1978). Prospects for a cognitive ethology. The Behavioral and Brain Sciences, 4, $527-538$. 
Güntürkün, O., \& Bugnyar, T. (2016). Cognition without cortex. Trends in Cognitive Science, 20, 291-303.

Güttinger, H. R. (1977). Variable and constant structures in greenfinch songs (Chloris chloris) in different locations. Behaviour, 60, 304-318.

Gutiérrez-Ibáñez, C., Iwaniuk, A. N., \& Wylie, D. R. (2018). Parrots have evolved a primate-like telencephalicmidbrain-cerebellar circuit. Scientific Reports, 8, 9960.

Howard, E. (1920). Territory and bird life. Williams Collins Sons \& Company, Limited.

Hulse, S. H., Fowler, H., \& Honig, W. K. (1978). Cognitive processes in animal behavior. Erlbaum.

Immelmann, K. (1984). The natural history of bird learning. In P. Marler \& H. S. Terrace (Eds.), The biology of learning, Dahlem Konferenzen (pp. 271-288). Springer-Verlag.

Jarvis, E. D. (2019). Evolution of vocal learning and spoken language. Science, 366, 50-54.

King, A. P., \& West, M. J. (1977). Species identification in the North American cowbird: Appropriate responses to abnormal song. Science, 195, 1002-1004.

King, A. P., \& West, M. J. (1983). Dissecting cowbird song potency: Assessing a song's geographic identity and relative appeal. Zeitschrift für Tierpsychologie, 63, 37-50.

Krebs, J. R. (1977). Song and territory in the great tit Parus major. In B. Stonehouse \& C. Perrins (Eds.), Evolutionary ecology (pp. 47-62). Macmillan.

Krebs, J. R., Ashcroft, R., \& Weber, M. (1978). Song repertoires and territory defence in the great tit. Nature, 271, 539-542.

Kroodsma, D. E. (1976). Reproductive development in a female songbird: Differential stimulation by quality of male song. Science, 192, 574-575.

Kroodsma, D. E. (1979). Vocal dueling among male marsh wrens: Evidence for ritualized expressions of dominance/subordinance. Auk, 96, 506-515.

Lawson, R. W., \& Lanning, D. V. (1980). Nesting and status of the Maroon-fronted parrot (Rhynchopsitta terrisi). In R. F. Pasquier (Ed.), Conservation of new world parrots (pp. 385-392). ICBP Tech. No. 1.

Levinson, S. T. (1980). The social behavior of the White-fronted Amazon (Amazona albifrons). In R. F. Pasquier (Ed.), Conservation of New World parrots (pp. 403-417). ICBP Technical Publication No. 1.

Lieberman, P. L. (1975). On the origins of language. Macmillan.

Lorenz, K. (1952). King Solomon's ring. Translated by M. K. Wilson. Harper \& Row.

Marler, P. (1952). Variation in the song of the chaffinch Fringilla coelebs. Ibis, 94, 458-472.

Marler, P. (1956). The voice of the chaffinch and its function as a language. Ibis, 98, 231-261.

Marler, P. (1961). The logical analysis of animal communication. Journal of Theoretical Biology, 1, $295-317$.

Marler, P. (1970). A comparative approach to vocal learning: Song development in white-crowned sparrows. Journal of Comparative and Physiological Psychology, 71, 1-25.

Marler, P. (1974). Animal communication. In L. Krames, P. Pliner, \& T. Alloway (Eds.), Nonverbal communication: Advances in the study of communication and affect (pp. 25-50). Plenum Press.

Marx, J. (1980). Ape-language controversy flares up. Science, 207, 1330-1333.

Nottebohm, F. (1966). The role of sensory feedback in the development of avian vocalizations [Unpublished doctoral dissertation]. University of California, Berkeley, CA.

Nottebohm, F. (1970). Ontogeny of bird song. Science, 167, 950-956.

Olkowicz, S., Kocourek, M., Lucan, R. K., Porteš, M., Fitch, W. T., Herculano-Houzel, S., \& Němec, P. (2016). Birds have primate-like numbers of neurons in the forebrain. Proceedings of the National Academy of Sciences, 113, 7255-7260.

Payne, R. B. (1982). Ecological consequences of song matching: Breeding success and intraspecific song mimicry in indigo buntings. Ecology, 63, 401-411.

Pepperberg, I. M. (1981). Functional vocalizations by an African Grey parrot (Psittacus erithacus). Zeitschrift für Tierpsychologie, 55, 139-160.

Premack, D. (1971). Language in chimpanzee? Science, 172, 808-822.

Price, T., Wadewitz, P., Cheney, D., Seyfarth, R., Hammerschmidt, K, \& Fischer, J. (2014). Vervets revisited: A quantitative analysis of alarm call structure and context specificity. Scientific Reports, 5, 13220.

Rasmussen, K. (1972). The Netsilik Eskimos. In J. Rothenberg (Ed.), Shaking the pumpkin (p. 45). Doubleday.

Rinnert, P., Kirschhock, M. E., \& Nieder, A. (2019). Neuronal correlates of spatial working memory in the endbrain of crows. Current Biology, 29, 2616-2624.

Rumbaugh, D. M., von Glasersfeld, E. C., Warner, H., Pisani, P., Gill, T. V., Brown, J. V., \& Bell, C. L. (1973). A computer-controlled language training system for investigating the language skills of young apes. Behavior Research Methodology and Instrumentation, 5, 385-392.

Sebeok, T. A., \& Rosenthal, R. (1981). The Clever Hans phenomenon: Communication with horses, whales, apes, and 
people. New York Academy of Sciences (Annals).

Seyfarth R. M., Cheney, D. L., \& Marler, P. (1980a). Monkey responses to three different alarm calls: Evidence of predator classification and semantic communication. Science, 210, 801-803.

Seyfarth, R. M., Cheney, D. L., \& Marler, P. (1980b). Vervet monkey alarm calls: Semantic communication in a free-ranging primate. Animal Behaviour, 28, 1070-1094.

Sherman, P. W. (1977). Nepotism and the evolution of alarm calls. Science, 197, 1246-1253.

Skinner, B. F. (1957). Verbal behavior. Appleton-Century-Crofts.

Slater, P. J. B. (1983). Bird song learning: Theme and variations. In G. A. Clarke, Jr., \& A. R. Brush (Eds.), Perspectives in ornithology (pp. 475-499). Cambridge University Press.

Smith, W. J. (1963). Vocal communication of information in birds. American Naturalist, 97, 117-125.

Snowdon, C. T., Brown, C. H., \& Peterson, M. R. (1982). Primate communication. Cambridge University Press.

Stephan, C., \& Zuberbühler, K. (2016). Social familiarity affects Diana monkey (Cercopithecus diana diana) alarm call responses in habitat-specific ways. Royal Society Open Science, 3, 150639.

Struhsaker, T. T. (1967). Auditory communication among vervet monkeys (Cercopithecus aethiops). In S. A. Altmann (Ed.), Social communication among primates (pp. 281-324). University of Chicago Press.

Thorpe, W. H. (1974). Animal and human nature. Doubleday.

Todt, D. (1975). Social learning of vocal patterns and modes of their applications in Grey parrots. Zeitschrift für Tierpsychologie, 39, 178-188.

Townsend, S. W., \& Manser, M. B. (2013). Functionally referential communication in mammals: The past, present and the future. Ethology, 119, 1-11.

Wade, N. (1980). Does man alone have language? Apes reply in riddles and a horse says neigh. Science, 208, 1349-1351.

Waser, P. M. (1977). Individual recognition, intra-group cohesion, and intergroup spacing: Evidence from sound playback to forest monkeys. Behaviour, 60, 28-74.

Weeden, J. S., \& Falls, J. B. (1959). Differential response of male ovenbirds to recorded songs of neighboring and more distant individuals. Auk, 76, 343-351.

Wheeler, B. C., \& Fischer, J. (2012). Functionally referential signals: A promising paradigm whose time has passed. Evolutionary Anthropology, 21, 195-205.

Yasukawa, K. (1981). Song repertoires in the red-winged blackbird (Agelaius phoeniceus): A test of the Beau Geste hypothesis. Animal Behaviour, 29, 114-125. 